Article

\title{
The Expression of ERK1/2 in Female Yak (Bos grunniens) Reproductive Organs
}

\author{
Jiangfeng Fan ${ }^{1, *}$, Xiaohong Han ${ }^{1}$, Honghong He ${ }^{1}$, Yuzhu Luo ${ }^{2} \mathbb{O}$, Sijiu Yu $^{1}$, Yan Cui ${ }^{3}$, \\ Gengquan $\mathrm{Xu}^{3}$, Libin Wang ${ }^{3}$ and Yangyang Pan ${ }^{3}$ \\ 1 College of Veterinary Medicine, Gansu Agricultural University, Lanzhou 730070, China; \\ hanxiaohong11@126.com (X.H.); honghong3h@126.com (H.H.); yusj@gsau.edu.cn (S.Y.) \\ 2 College of Animal Science and Technology, Gansu Agricultural University, Lanzhou 730070, China; \\ luoyz@gsau.edu.cn \\ 3 Technology and Research Center of Gansu Province for Embryonic Engineering of Bovine and Sheep \& Goat, \\ Lanzhou 730070, China; cuiyan369@sina.com (Y.C.); xugq0307@aliyun.com (G.X.); \\ Wanglb@gsau.edu.cn (L.W.); panyy@gsau.edu.cn (Y.P.) \\ * Correspondence: fanjf@gsau.edu.cn; Tel.: +86-13609360354; Fax: +86-931-7631229
}

Received: 3 February 2020; Accepted: 16 February 2020; Published: 20 February 2020

check for updates

Simple Summary: Extracellular signal-regulated kinases1/2 (ERK1/2) plays a significant role in regulating the reproductive processes of mammals. The goal of our research is to investigate the expression and distribution of ERK1/2 in the main reproductive organs of the yak during different stages. Using immunohistochemistry, western blot, and relative quantitative real-time polymerase chain reaction techniques, we found that the expression of ERK1 and ERK2 proteins and their mRNA in the yak's ovary, oviduct, and uterus varies with the stage of the reproductive cycle. The variation character of ERK1 and ERK 2 expression in the yak's main reproductive organs during different stages implies that they play an important role in regulating the reproductive functions under different physiological statuses.

Abstract: The main reproductive organs undergo different histological appearances and physiological processes under different reproductive statuses. The variation of these organs depends on a delicate regulation of cell proliferation, differentiation, and apoptosis. Extracellular signal-regulated kinases1/2 (ERK1/2) are members of the mitogen-activated protein kinase (MAPK) super family. They have important roles in regulating various biological processes of different cells, tissues, and organ types. Activated ERK1/2 generally promotes cell survival, but under certain conditions, ERK1/2 also have the function of inducing apoptosis. It is widely believed that ERK1/2 play a significant role in regulating the reproductive processes of mammals. The goal of our research is to investigate the expression and distribution of ERK1/2 in the yak's main reproductive organs during different stages. In the present study, samples of the ovary, oviduct, and uterus of 15 adult female yak were collected and used in the experiment. The ERK1/2 proteins, localization, and quantitative expression of their mRNA were investigated using immunohistochemistry (IHC), western blot (WB) and relative quantitative real-time polymerase chain reaction (RT-PCR). The results indicated that ERK1/2 proteins and their mRNA were highly expressed in the ovary of the luteal phase and gestation period, in the oviduct of the luteal phase, and in the uterus of the luteal phase and gestation period. Immunohistochemical analysis revealed a strong distribution of ERK1/2 proteins in follicular granulosa cells, granular luteal cells, villous epithelial cells of the oviduct, endometrial glandular epithelium, and luminal epithelium. These results demonstrated that the expression of ERK1 and ERK2 proteins and their mRNA in the yak's ovary, oviduct, and uterus varies with the stage of the reproductive cycle. The variation character of ERK1 and ERK 2 expression in the yak's main reproductive organs during different stages implies that they play an important role in regulating the reproductive function under different physiological statuses. 
Keywords: yak; ERK1/2; ovary; oviduct; uterus

\section{Introduction}

Extracellular signal-regulated kinases (ERKs) are an important subfamily of mitogen-activated protein kinases (MAPKs), which regulate various cellular activities and physiological processes. Originally, the ERK gene was isolated from the expression library of human gastric cancer in 1993 [1,2], and it was recognized as a genomic DNA, encoding a sequence of the receptor protein-tyrosine kinase. The ERK gene is evolutionarily conserved, and is found in all eukaryotes, from yeast to humans [3]. Activated ERK mediates extracellular signals (transferring from cell membrane receptors to cytoplasm and nuclear effectors) and regulates some specific gene expression by phosphorylating transcription factors; thus, participates in the regulation of cell growth, development, differentiation, and proliferation. By now, it is well known that the classical ERK cascade consists of Rafs (MAP3K), mitogen-activated protein kinase 1/2 (MEK1/2), extracellular signal-regulated kinases1/2 (ERK1/2), and several MAPK-activating protein kinases (MAPKAPKs) [4]. ERK1/2, also known as mitogen-activated protein kinases 3 and 1 (MAPK3/1), is one of the major MAPK cascades. Thus, MEK1/2, MAP3Ks, and other upstream signals can persistently, or transiently, activate ERK1/2. Activated ERK1/2 generally promote cell survival, but under certain conditions, ERK1/2 also have the function of inducing apoptosis [5].Many different stimuli, including growth factors [6], radiation [7,8], osmotic stress [9,10], Fas ligand [11], nitric oxide [12], and hydrogen peroxide [13] activate the ERK1/2 pathway. Remarkably, some researchers have indicated that activated ERK1/2 can inhibit apoptosis induced by hypoxia condition [14-17]. Thus, it is widely believed that ERK1/2 play an important role in mammalian organ development, incorporating with cellular proliferation, differentiation, migration, fate determination, growth, and apoptosis [18]. There are a number of materials reporting the expression of ERK1 and ERK2 in almost all kinds of tissues and cells, such as the brain, lung, gastrointestinal tract, testis, and some kind of cancer cells [19]. In an overall view, the function and mechanism of ERK1/2 vary under different circumstances and physiological statuses [20]. Similarly, some experiments have shown that the expression of ERK1 and ERK2 are widely presented in different parts of the reproductive organs in mammals and poultry [21-32]. However, the whole profile and specific role of ERK1/2 expression in reproductive organs, along with the different reproductive cycle stages, have not yet been detected and analyzed clearly in mammals.

The yak (Bos grunniens) is a kind of seasonal breeding-mammal that is mostly allocated around the Qinghai-Tibet Plateau [33]. Because of their predominant adaptability to high altitude, cold conditions, nutrition deficiency, and hypoxia environments, yaks have always been believed to be the most important means of production and livelihood of local herdsmen [34]. However, affected by formidable natural conditions, the yak presents a very low reproductive efficiency. The majority of them can give birth only once every two years or twice every three years $[35,36]$. Therefore, it is an important aspect-for improving the reproductive efficiency-to investigate the regulation of breeding activities [37-39]. Similar to other mammals, the female reproductive organs of adult yaks experience cyclic variation during different stages of their reproductive cycles. Ovary follicle development, corpus luteum generation, luteolysis, uterine distention, and placentation take place at specific periods $[22,40,41]$. Along with the reproductive cycle, numerous cells, such as ovarian granular cells, luteal cells, endometrial epithelium cells, and endometrial stromal cells experience proliferation or apoptosis [42]. As previously noted, ERK1/2 are involved in cell growth, differentiation, and apoptosis. All of these processes occur in the ovary and uterus during normal reproductive cycles. Therefore, it should be an attractive prospect to explore the roles and regulatory mechanisms of ERK1/2 in yak reproduction. We hypothesized that the abundance of ERKs would fluctuate in the reproductive tract during the different reproductive situations. 


\section{Materials and Methods}

\subsection{Samples of Yak's Reproducitve Organs}

All procedures involving animals were approved by the Animal Care and Use Committee of Gansu Agricultural University. Samples of ovaries, oviducts, and uterus were incised from yaks (5 yaks per group) within 10 min after being slaughtered, in Xining abattoir of Qinghai Province, China. The yaks used for sample collection were estimated to be between 5 and 8 years old, were inspected to have no clinical disease, and no obvious pathological changes. For mRNA and protein analysis of ERK1/2 expression using WB and RT-PCR, tissue samples were immersed into liquid nitrogen for storage immediately after washing with $0.1 \%$ diethylpyrocarbonate (DEPC) reated water. Another tissue sample of the same yak was cut into small pieces and fixed with $4 \%$ paraformaldehyde phosphate buffer ( $\mathrm{pH} 7.3$ ) in $4{ }^{\circ} \mathrm{C}$, at least 2 weeks before subsequent use.

According to the status of the yak's reproductive organ, we divided these tissue samples into 3 groups. The follicular phase group: there was only one $\geq 10.0 \mathrm{~mm}$ follicle and no macroscopically corpus luteum in both ovaries; the two uterine horns were symmetric and not dilated. The luteal phase group: there was only one $\geq 10.0 \mathrm{~mm}$ functional corpus luteum and no $>8.0 \mathrm{~mm}$ follicle. Smaller luteum existed in both ovaries, and the two uterine horns were symmetric, not dilated. The gestation period group: functional corpus luteum was present in one of the two ovaries; one side of the uterine horns was obviously dilated and contained fetal.

\section{2. erk1 and erk2 Gene Expression Analysis}

Total RNA of yak tissue samples of every group were extracted using TRIzol reagent (Invitrogen, Carlsbad, CA, USA). Experion RNA StdSens Analysis Kit (BioRad, Munich, Germany) was used for total RNA quality and quantity assessment on Experion Automated Electrophoresis Station (BioRad, Munich, Germany). The value of RNA quality indicator (RQI) adopted was between 5 and 10. To avoid genomic DNA contamination, enzymatic digestion was performed with RNase-free DNase I (Omega, Norcross, GA, USA). Subsequently, with MOligo-dT18 primers, total RNA was reverse transcribed into cDNA using RevertAid first Strand cDNA Synthesis Kit (Promega, Mannheim, Germany). For relative quantitative analysis of gene expression, the erk1 and erk2 primers were designed according to bovine sequences (NM001110018.1, NM175793.2), and $\beta$-actinprimers were designed based on the yak sequences (NM001034034.2). erk1 (F: 5'-ATCCCTTGGCTGTCG-3', R: 5'-AGGCGTTTCCATTCGT-3'). erk2 (F: 5'-ATCCCTTGGCTGTCG-3', R: 5' -AGGCGTTTCCATTCGT-3'). $\beta$-actin(F: 5'-AGGCTGTGCTGTCCCTGTATG-3' , R: 5'-GCTCGGCTGTGGTGGTAAA-3'). The predicted product length of these primers was 107,111 , and $187 \mathrm{bp}$, respectively. Real-time fluorescent quantitative PCR system (Light Cycler 480, Roche, Germany) was used to perform Real Time PCR analysis, as previously described [41]. Briefly, $200 \mathrm{ng}$ of total cDNA was amplified in a $20 \mu \mathrm{L}$ reaction mixture containing $10 \mu \mathrm{L}$ SYBR Premix Dimer Eraser (Promega, Mannheim, Germany) and $100 \mathrm{nM}$ of forward and reverse primer. The optimized 0conditions of RT-PCR were listed as below: pre-denaturation at $95{ }^{\circ} \mathrm{C}$ for $4 \mathrm{~min}$, denaturing 40 cycles at $95{ }^{\circ} \mathrm{C}$ for $30 \mathrm{~s}$, annealing at $58{ }^{\circ} \mathrm{C}$ for $30 \mathrm{~s}$, and extension fluorescence acquisition at $72{ }^{\circ} \mathrm{C}$ for $25 \mathrm{~s}$. The specificity analysis was performed through melting curve from $65{ }^{\circ} \mathrm{C}$ to $95^{\circ} \mathrm{C}$ in $0.5{ }^{\circ} \mathrm{C}$ steps, each lasting $5 \mathrm{~s}$, and the product was conduct electrophoresis in $2.5 \%$ agarose gel to confirm correct size.

\subsection{The Quantitative Analysis of ERK1/2 Proteins Expression}

For quantitative analysis of ERK1 and ERK2 proteins expression, frozen tissues were taken out of liquid nitrogen. After, they were washed with cold phosphate buffer saline (PBS) for three times. The total proteins of samples were extracted using Beyotime extraction buffer, and the protein concentration was detected via Bradford assay kit (Bio-Rad, Hercules, CA, USA). Then, the protein suspension was conducted, electrophoresis (PAGE), filled on 10\% SDS-PAGE gel. Subsequently, separated proteins were electrophoretically transferred onto enhanced chemiluminescence (ECL) 
polyvinylidene fluoride (PVDF) membranes (Amersham, Piscataway, NJ, USA), using a mini transfer instrument for electrophoresis (Bio-Rad, Hercules, CA, USA) at $300 \mathrm{~mA}$ for $90 \mathrm{~min}$. After, it was blocked with Tris-buffered saline (contained 5\% non-fat dry milk and $0.1 \%$ Tween-20) the protein was incubated with a primary antibody against ERK1/2 (p44/42 MAPKRabbit mAb, 4695 s, CST, Danvers, MA, USA) and $\beta$-actin ( $($-Actin Rabbit mAb, 4970 s, CST, Danvers, MA, USA) in Tris-buffered saline at $37{ }^{\circ} \mathrm{C}$ for $2 \mathrm{~h}$. After, it was washed in Tris-buffered saline, the protein reacted with a secondary antibody (goat anti-rabbit immunoglobulin G conjugated with horseradish peroxidase, sc-2030, Santa Cruz Biotechnology, Santa Cruz, CA, USA) under $37^{\circ} \mathrm{C}$ for another $2 \mathrm{~h}$. After it was washed with Tris-buffered saline, the membrane reacted with ECL Substrate kit (ab65623, Abcam, Cambridge, UK). For negative controls (were conducted using normal IgG reagent) replaced the primary antibodies. The protein band's intensity on the membranes was measured using the densitometric analysis system (Bio-Rad, Hercules, CA, USA). Relative intensity of ERK1/2 proteins were normalized with $\beta$-actin bands.

\subsection{Localizational Analysis of ERK1/2 Proteins Expression}

The localization of ERK1/2 proteins was analyzed on paraffin-embedded $4 \mu \mathrm{m}$ tissue sections using the immunohistochemical technique. At first, paraffin-embedded tissue sections were dewaxed and rehydrated using gradient acetone and alcohol solution, and eliminated endogenous peroxidase activity by incubating with $3 \% \mathrm{H}_{2} \mathrm{O}_{2}$ for $5 \mathrm{~min}$. Then, the tissue sections were immersed in citrate buffer ( $\mathrm{pH}$ 6.0) and boiled for $10 \mathrm{~min}$ to enhance the antigen activity. Subsequently, for reducing non-specific binding of the primary antibody, sections were incubated with normal goat blocking serum for 15 min after being thoroughly washed with PBS. After that, tissue sections were incubated with primary antibody (1:450 diluted p44/42 MAPK Rabbit mAb, 4695 s, Cell Signaling Technology, Inc., Danvers, MA, USA) at $37{ }^{\circ} \mathrm{C}$ for $120 \mathrm{~min}$, followed by incubation with secondary antibody (biotinylated goat anti-rabbit IgG, Invitrogen Zymed Laboratories, Carlsbad, CA, USA) for 15 min at $37^{\circ} \mathrm{C}$. Then, sections were washed another three times in PBS and reacted with avidin-biotin peroxidase. The immunoperoxidase color reaction was completed by adding 3,3'-diaminobenzidine agent (DAB, Invitrogen Zymed Laboratories, Carlsbad, CA, USA) as substrate. After a moderate brown reaction product presented, tissue sections were timely washed with PBS to stop color reaction. In the end, after being counterstained with haematoxylin, tissue sections were mounted with resin, for observation under microscope and storage. We also performed the negative controls experiment by replacing the primary antibody with normal non-immune IgG agent.

\subsection{Data Analysis}

The relative quantity of erk1 and erk 2 mRNA and protein expression are presented as fold increase, where expression of target mRNA or proteins was divided by the expression of $B$-Actin. The difference of expression quantity between reproductive stages was analyzed by one-way ANOVA procedure using SPSS 19.0 (SPSS Inc., Chicago, USA). It was considered to be statistically significant at a probability of $p<0.05$; meanwhile, extremely significant was defined as $p<0.01$.

\section{Results}

\section{1. $m R N A$ Expression of erk1 and erk2 in Female Yak Reproductive Organs}

A variation of erk1 and erk2 gene expression was detected in female yak reproduction organs during different stages of the reproductive cycle. In the ovary, the erk1 gene expression was significantly higher in the luteal phase $(p<0.05)$ and gestation period $(p<0.01)$ than the follicular phase. Similar to erk1, the mRNA level of erk2 was also higher in the luteal phase compared with the follicular phase and gestation period $(p<0.05)$, but no significant difference existed between gestation period and follicular phase $(p>0.05)$. In the oviduct, the level of the erk1 gene expression was highest in the luteal phase, which was significantly different with that in the follicular phase and gestation period $(p<0.05)$. 
However, the erk2 gene expression was extremely higher in the follicular phase than in the luteal phase $(p<0.05)$ and gestation period $(p<0.01)$. In the uterus, the erk1 gene expression was extremely higher in the luteal phase and gestation period than in the follicular phase $(p<0.05)$, although no significant difference was found between the luteal phase and gestation period. Similarly, the level of erk2 gene expression was also higher in the luteal phase and gestation period than that in the follicular phase $(p<0.05)$ (Figure 1).

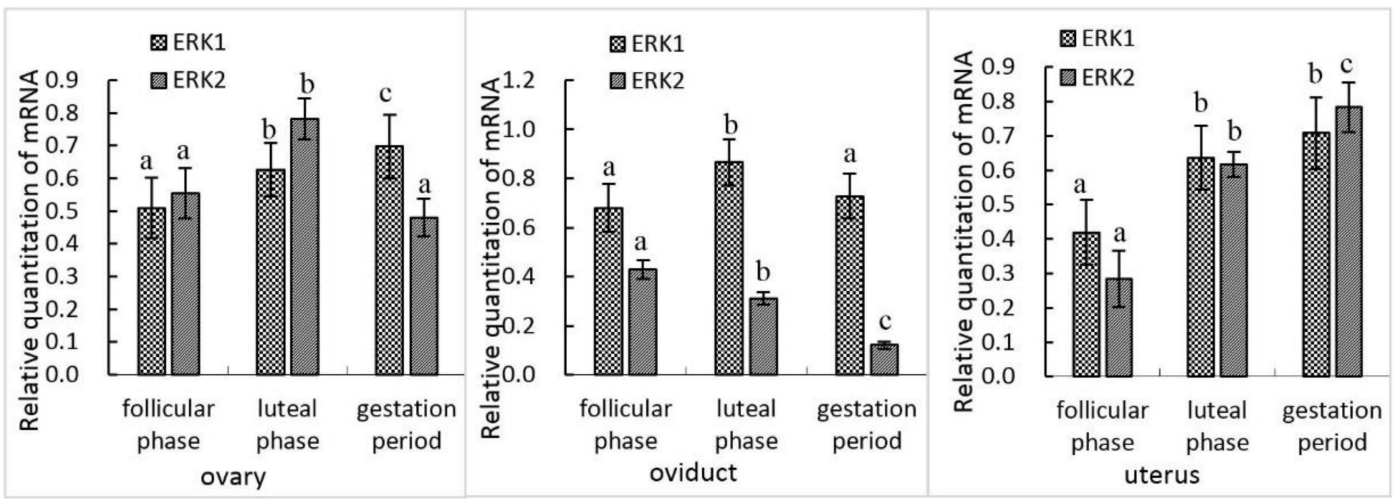

Figure 1. Expression of extracellular signal-regulated kinase (ERK)1 and ERK2 mRNA in female reproductive organs at different stages. In a certain reproductive organ, the difference of the same protein between $\mathrm{a}$ and $\mathrm{b}$ or $\mathrm{b}$ and $\mathrm{c}$ is significant $(0.05>p>0.01)$, and the difference of the same protein between a and $\mathrm{c}$ is extremely significant $(p<0.01)$.

\subsection{ERK1 and ERK2 Protein Expression in the Female Yak's Reproductive Organs}

Both ERK1 and ERK2 proteins were detected using the western blotting technique. The characteristics of ERK1 and ERK2 protein expression in the female yak's reproductive organs at different reproductive statuses were similar as their mRNA expression. In ovaries, the level of ERK1 protein expression was nearly twofold of $\beta$-actin during the gestation period, while it only approximated one-half of $\beta$-actin in the follicular phase. The difference between these two stages was extremely significant $(p<0.01)$. The expression of ERK2 was higher in the luteal phase than that in the follicular phase and gestation period $(p<0.05)$. A little higher ERK2 expression was also found in the gestation period compared with the follicular phase, although there was no significant difference between these two groups $(p>0.05)$. In the oviduct, the level of ERK1 protein expression was highest in the luteal phase, which was significantly different with that in the follicular phase and gestation period $(p<0.01)$. However, ERK2 protein expression was extremely higher, in both the follicular phase and luteal phase, than that in the gestation period $(p<0.01)$. In the uterus, both ERK1 and ERK2 protein expressions were extremely higher in the luteal phase and gestation period, compared with the follicular phase $(p<0.01)$, although the difference between the luteal phase and gestation period was not significant (Figure 2). 


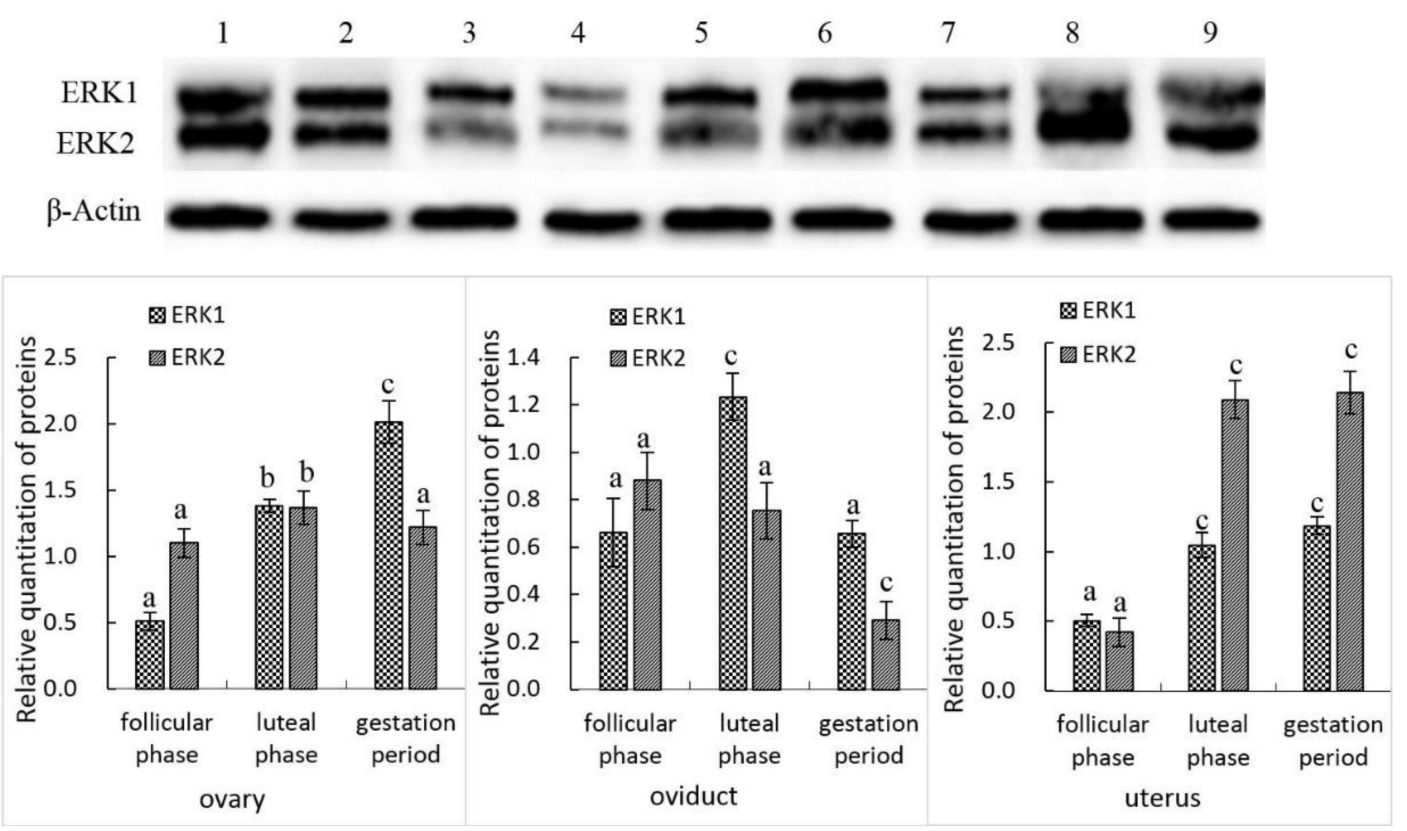

Figure 2. The western blot bands and expression analysis of ERK1, ERK2, and $\beta$-Actin proteins; 1, 2, 3: ovary; 4, 5, 6: oviduct; 7, 8, 9: uterus; 1, 4, 7: follicular phase; 2, 5, 8: luteal phase; 3, 6, 9: gestation period. Note: In certain reproductive organs, the difference of the same protein between $a$ and $b$ or $b$ and $\mathrm{c}$ is significant $(0.05>p>0.01)$, and the difference of the same protein between a and $\mathrm{c}$ is extremely significant $(p<0.01)$.

\subsection{Immunolocalization of ERK1/2 Proteins in the Female Yak's Reproductive Organs}

Immunohistochemical analysis revealed a light to dense positive reaction accumulation of signals for ERK1/2 proteins in the female yak's reproductive organs under different reproductive statuses. In the ovary, ERK1/2 proteins were mainly expressed in surface epithelium, follicular granulosa cells, ovarian stroma, vascular endothelium, and corpus luteum. In particular, in the corpus luteum of the gestation period, most granular luteal cells were stained into strong brown, while membranous luteal cells were not stained. However, the overall signal intensity of ERK1/2 proteins in the ovary of the luteal phase was less pronounced compared with that of the follicular phase and gestation period (Figure 3A-C). In the oviduct, the positive accumulations of signals for ERK1/2 proteins localized moderately in villous epithelial cells, and some dispersed villous stromal cells. The intensity of ERK1/2 proteins expression was slightly higher in the oviduct of the luteal phase and the follicular phase compared with that of the gestation period (Figure $3 \mathrm{E}-\mathrm{G}$ ). In the uterus, the main compartments of ERK1/2 protein expressions were endometrial luminal epithelium, glandular epithelium, endometrial stroma, and vascular endothelium. In addition, ERK1/2 protein signals also moderately appeared in the myometrium of the luteal phase and gestation period. The signal intensity of ERK1/2 proteins in the uterus of luteal phase and gestation period was obviously higher than that of the follicular phase (Figure 3I-K). 


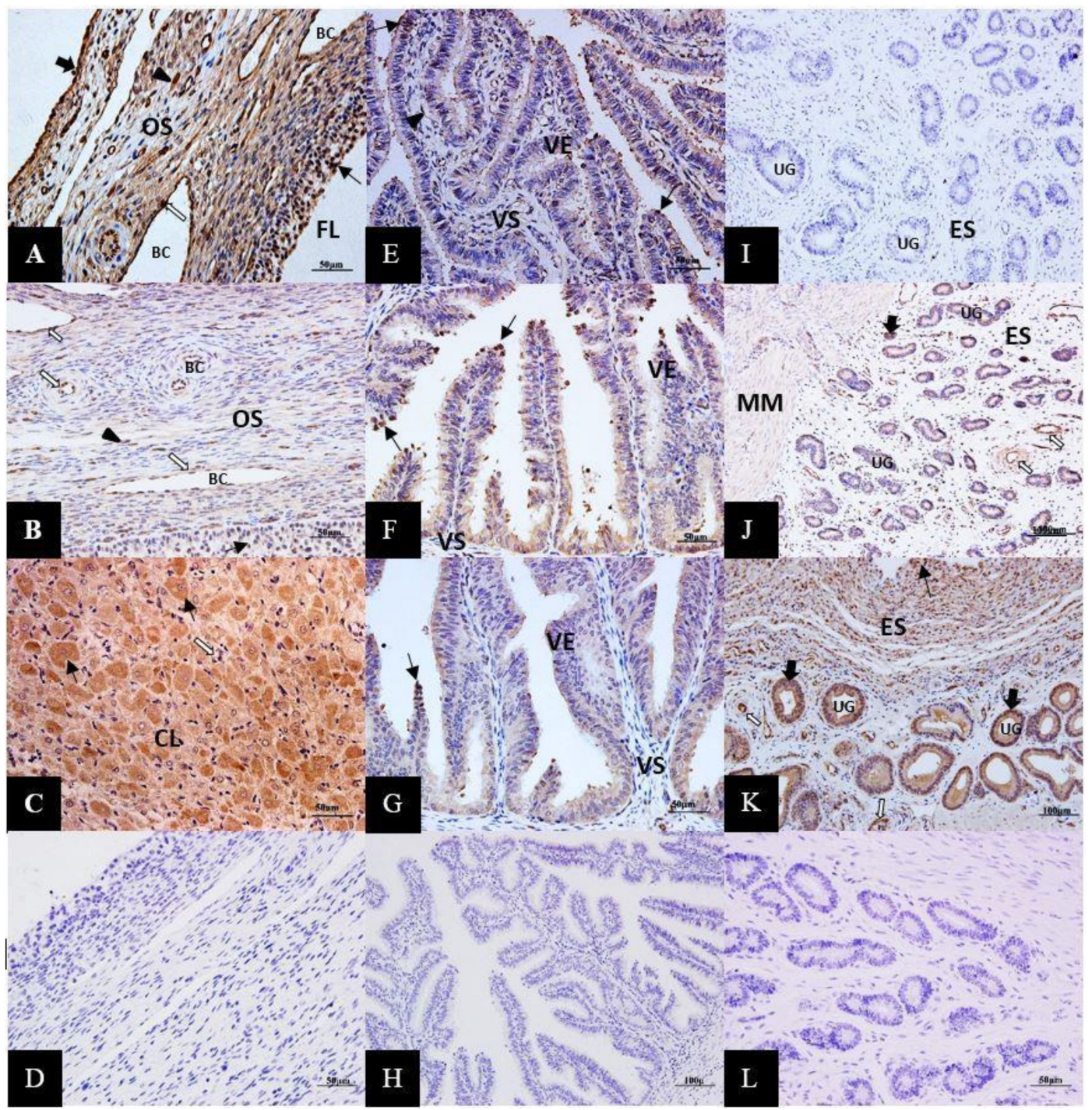

Figure 3. Immunolocalization of ERK1/2 proteins (brown stained regions) in the female yak's ovary $(\mathbf{A}, \mathbf{B}, \mathbf{C})$, oviduct $(\mathbf{E}-\mathbf{G})$, and uterus $(\mathbf{I}, \mathbf{J}, \mathbf{K})$ during the follicular phase $(\mathbf{A}, \mathbf{E}, \mathbf{I})$, luteal phase $(\mathbf{B}, \mathbf{F}, \mathbf{J})$, and gestation period $(\mathbf{C}, \mathbf{G}, \mathbf{K})$. (A) ERK1/2 appeared in follicular granulosa cells (thin arrow), ovarian stroma cells (arrowhead), vascular endothelium (thick arrow), and surface epithelium (white thick arrow) of the ovary during the follicular phase. (B) ERK1/2 proteins moderately expressed in vascular endothelium (thick arrow), vascular endothelium (thick arrow), and follicular granulosa cells (thin arrow) of the ovary during the luteal phase. (C) Most of granular luteal cells (thin arrow) were stained into strong brown, while membranous luteal cells (white thick arrow) in corpus luteum of gestation period. (D) Negative control, ovary tissue sections were incubated with an equivalent non-immune IgG agent instead of a rabbit polyclonal antibody to ERK1/2. (E,F,G). The positive reaction of ERK1/2 proteins moderately localized in villous epithelial cells (thin arrow) and some dispersed villous stromal cells (arrowhead) of the oviduct. The intensity of ERK1/2 proteins expression was slight higher in the luteal phase (F) and follicular phase (E) compared with that of the gestation period (F). (H) Negative control of oviduct sections. (I,J,K) The main compartments of the ERK1/2 protein expression were endometrial epithelium (thin arrow), glandular epithelium (thick arrow), endometrial stroma cells (arrowhead), and vascular endothelium (white thick arrow) of the uterus. The signal intensity of ERK1/2 proteins in the uterus of the luteal phase $(\mathbf{J})$ and gestation period $(\mathbf{K})$ was obviously higher than that of the follicular phase (I). (L) Negative control of the uterus section. FL: follicle, BC: blood capillary, OS: ovarian stroma, CL: corpus luteum, VE: villous epithelium, VS: villous stroma, UG: uterine gland, ES: endometrial stroma, MM: myometrium. 


\section{Discussion}

The present study described the expression of ERK1 and ERK2 proteins and mRNA in female reproductive organs of the adult yak during different the stage of the reproductive cycle based on RT-PCR, western blot, and immunohistochemistry analysis. The results showed that both the intensity and distribution of ERK1 and ERK2 expression in the ovary, oviduct, and uterus varied with the stage of the reproductive cycle. In general, the expression of ERK1 and ERK2 proteins and mRNA was most pronounced in the ovary of the luteal phase and gestation period, the oviduct of the luteal phase and the uterus of the gestation period. The histological appearance and physiological process of the main reproductive organs also varies with the different reproductive stages [43].

In the ovary, the results of the present study indicated that both the ERK1 and ERK2 proteins and mRNA were highly expressed during the luteal phase and gestation period, and the immunohistochemical analysis revealed an intense distribution of the ERK1/2 protein in follicular granulosa cells and corpus luteum cells. It is well know that the ovary is a highly organized composite of oocytes, granulosa cells, stromal cells, and sometimes corpus luteum cells whose interaction induce development of follicles, ovulation, formation of corpus luteum, and luteolysis during different stages of the reproductive cycle; many factors involved in the regulation mechanism of the ovary's physiological process. The classical point of view believes that the development of the ovary is mainly regulated by the hypothalamic-pituitary-ovarian axis. Therefore, various reproductive hormones play a very important role as external signals. Recently, studies have focused on the role and pathway of intra-ovarian signaling cascades in regulating ovary development [44]. As we discuss in the present study, ERK1/2 is one of the important intra-ovarian regulators of ovary development in mammals. The ERK1/2 pathway is intensively studied in follicle development of mice and other mammal species [45-48]. It has been reported that ERK1/2, and some other protein kinases, impact the cumulus expansion and oocyte maturation of porcine cumulus oocyte complexes (COCs) by inducing the expression of both the epidermal growth factor (EGF)-like factor and its protease [49]. Using cultured primary rat granulosa, Wayne et al. proved that follicle-stimulating hormone (FSH) and luteinizing hormone (LH) control granulosa cell function and differentiation by activating Ras protein, and some downstream kinases, especially MEK1 and ERK1/2 [50]. On the contrary, the experiment conducted on gene knockout mice and pharmacologically inhibited materials also demonstrated a pivotal role of the ERK1/2 pathway in ovulatory processes [51-53]. Most recently, by injection of pharmacological inhibitor (PD0325901) of ERK1/2 into the pre-ovulatory dominant follicle, Yasmin et al. found that four of five cows failed to ovulate, and 285 differentially expressed genes were identified from granulosa cells of drug treated follicles. Based on the analysis of the differentially expressed genes, they further affirmed a significant role of ERK1/2 in mediating LH induced gene expression in ovulating follicles, and the physiological process of ovulation dependent on proper ERK1/2 signaling in bovine [25]. Ryan et al. also found that the level of ERK signal proteins was different between dominant and subordinate follicles early in the stage of dominant follicle selection in cows [26]. However, there is no report about the expression of ERK1/2 in the ovary of the yak. The mass emergence of the ERK1/2 protein in follicular granulosa cells, demonstrated by the present study, probably means that the follicular development and further ovulation is a physiological process dependent on the regulation of ERK1/2.

Our study also demonstrates an intense expression of ERK1/2 in corpus luteum of the luteal phase and gestation period. It is well known that corpus luteum is a transient endocrine tissue that is derived from a pre-ovulatory follicle (Graffian follicle). It plays a significant role in controlling the reproductive cycle of mammals. The degeneration of corpus luteum, in case of un-pregnancy, is a key event for the initiation of a new reproductive cycle, re-ovulation, and obtaining the next chance of conception. On the contrary, the prolongation of the luteal function is also essential for the development of the embryo and maintenance of pregnancy relationship [54]. Generally, prostaglandin $\mathrm{F}_{2 \alpha}\left(\mathrm{PGF}_{2 \alpha}\right)$, as an extra-ovarian physiological luteolysin derived from uterus, is the key factor inducing the degeneration of the corpus luteum. It is well recognized that apoptosis is the main mechanism of $\mathrm{PGF}_{2 \alpha}$ induced regression of corpus luteum in bovine and other mammals [54]. As an important regulatory factor 
of apoptosis and proliferation of many types of cells, ERK1/2 is also involved in the mechanism of regression and functional maintenance of corpus luteum. For example, Maekawa et al. have found that human chorionic gonadotrophin (hCG) increased the StAR gene (coding histone modification enzymes) expression in granulosa cells through the ERK1/2 mediated signal pathway in the physiological process of follicular luteinization [55]. This is one of a few reports about the role of ERK1/2 in luteal formation. Strikingly, numerous research indicates that ERK1/2 is related to the regression of corpus luteum. Based on the experiment performed on Sprague-Dawley rats, Choi et al. found that PGF2 $\alpha$ inducted luteal cell autophagy was accompanied with the activation of ERK1/2 during corpus luteum regression, and it is not regulated by the mammalian target of rapamycin (mTOR) signal [27]. Qi L et al. also proved that prostaglandin F (PGF) treatment increased ERK1/2 and signal transducers and activators of transcription 3 (STAT3) phosphorylation, and this is a probable molecular mechanism of luteal regression in pseudopregnant rats [56]. A similar conclusion was obtained by Chen, who demonstrated that ERK1/2 signaling cascade can be activated by other molecular mechanisms in bovine luteal cells [57].

In addition, many different stimuli can induce the change of intracellular signal transduction. To analyze the change of intracellular mitogen-activated protein kinase (MAPK) signaling cascade induced by stress-related signaling events. Rueda et al. detected the phosphorylation level of main MAPK members in cultured luteal cells. They found that both jun-n-terminal kinase (JNK) and p38MAPK were highly phosphorylated after UV treatment, but the phosphorylation of ERK1 and ERK2 was low. In addition, all of these changes were related to a high apoptosis rate of in vitro cultured luteal cells. Based on these experimental results, they believed that stress signals induced regression of corpus luteum, perhaps mediated by the activation of MAPK cascade [58]. As we have mentioned above, the yak is a kind of livestock living in a very harsh environment. In particular, the gestation period of the female yak is mainly spent in winter and spring, when low temperature, hypoxia, and nutrition deficiency threaten them at all times. The high expression of ERK1/2 in corpus luteum perhaps is a mechanism to maintain the luteal function and pregnancy; thus, yaks developed a prominent adaptability to the rigorous natural environment.

In the oviduct, our present study has also found a more intense expression of both ERK1 protein and mRNA in the luteal phase compared with the follicular phase and gestation period of the female yak reproductive cycle. Further immunolocalization analysis indicated that ERK1/2 proteins mainly localized in villous epithelial cells. As we all know, the mammalian oviduct is a convoluted tube bridging the ovary and the uterus in the reproductive process of mammals. It also provides a suitable place for fertilization and development of preimplantation embryos. The function of the ovary and uterus in reproductive activities is always an important issue attracting great attention, and has widely been investigated for a long times. However, it seems that we neglect the importance of the oviduct in reproduction, and relative information about the oviduct is insufficiently. Recently, some researchers begin to focus on the important role of the oviduct, both in natural fertilization and in pre-implantation embryo development. The correct biophysical function, such as a moderate and rhythmic smooth muscle contraction, ensures the transportation of the gametes and zygote in the oviduct. Meanwhile, a suitable biochemical component of the oviduct content provides an adapt circumstance for the development of the preimplantation embryo. On the contrary, the incorrect function of the oviduct may be the result in infertility, or deficiency of the embryonal development $[59,60]$. The oviduct content, also named as oviduct fluid, consists of proteins secreted by the secretory cells of the oviduct epithelium and other plasma-derived constituents [61,62]. Therefore, a normal function of this epithelium and its secretions is a basic requirement for successful fertilization and establishment of pregnancy. Recently, numerous genes and proteins were identified involving in the regulation of oviduct functions, using transcriptomic and proteomic techniques [63]. For instance, Cerny et al. performed a transcriptome analysis of bovine oviduct epithelial cells, and they found that a large number of genes differentially expressed during different estrus stages [64]. In line with these observations, significant differences of the profile of the gene and protein expression in the oviduct, between different estrus cycle stages, have also been reported in ewes [65], bovine [66], pigs [67,68], and humans [69,70]. For example, 
in spontaneous estrous ewes, a total of 280 proteins were identified in the oviduct, and 64 proteins upregulated during estrus, while 17 proteins were upregulated in the luteal phase [65]. However, there is no report about the expression of ERK1 and ERK2 in the oviduct of the mammalian species.

The result obtained from the oviduct of different stages of the yak's reproductive cycle in the present study suggests that, as an intracellular signal transduction pathway, ERK1/2 plays a significant role in regulating the secretory activity of the oviduct epithelium, and provides an optimal oviduct microenvironment for oocyte fertilization and embryo development before implantation.

In the uterus, we also observed a more strong expression of ERK1 and ERK2 during the luteal phase and gestation period. The positive reaction of the ERK1/2 proteins were located strongly in the endometrial epithelium cells, stroma cells, and moderately in the uterine smooth muscle cells. In the follicular phase, under the stimulation of high concentrations of FSH and LH, follicular recruitment and abundant $\mathrm{E}_{2}$ secretion take place in the ovary, but the endometrium thickness and $\mathrm{P}_{4}$ level are minimal. In the same times, numerous of endometrial epithelium cells undergo degeneration and necrosis [71,72]. After ovulation (luteal phase), a new corpus luteum begins to develop and produces a large amount of progesterone. Then, the differentiation and proliferation of the endometrial epithelium cells take place under the stimulation of progesterone, to make preparation for embryo implantation [71,72].

The essential role of $\mathrm{P}_{4}$ and $\mathrm{E}_{2}$ in regulating endometrial differentiation, growth, and receptivity to implantation during primate menstrual cycle has been widely recognized [73-76]. Numbers of reports also demonstrated that MAPK signaling pathways are activated in the uterus during the process of embryos implantation in the rat [75,77] and human [78]. Sayem's experiment indicated that in female rats, thyroxin treatment increased the expression of ERK1/2 proteins in uterine stroma, which could help the uterine to adopt the implantation of embryos [79]. However, most of the materials are obtained from the estrus cycle or early gestation period (before embryo implantation). A few researchers also pay attention to the role of ERK in the uterus during the whole gestation period. For example, Welshet al. proved that estrogenic actions were mediated by the estrogen receptor $\alpha$ via activating ERK signals in human myometrium during pregnancy [80].

According to the analysis above, we consider that the expression of ERK1 and ERK2 in yak's endometrial glandular and luminal epithelial cells and uterine smooth muscle cells during the luteal phase and gestation period may play an important role in glandular secretion, and maintain an appropriate muscle tension of the uterus. This is essential for embryo implantation and subsequent development.

\section{Conclusions}

The present study firstly demonstrates the wide expression of ERK1 and ERK2 proteins and mRNA in female reproductive organs of the adult yak. The intensity of ERK1 and ERK2 proteins and their mRNA expression in the yak's ovary, oviduct, and uterus varies with the stage of the reproductive cycle. The variation character of ERK1 and ERK 2 expression in the yak's main reproductive organs during different stages implies that they play an important role in the regulation of reproductive functions under different physiological situations.

Author Contributions: Conceptualization, J.F. and S.Y.; methodology, Y.P. and H.H.; software, X.H.; validation, J.F., Y.L. and S.Y.; formal analysis, Y.C.; investigation, X.H. and H.H.; resources, G.X. and L.W.; data curation, X.H.; writing-original draft preparation, X.H.; writing-review and editing, J.F.; visualization, Y.C.; supervision, S.Y.; project administration, J.F.; funding acquisition, J.F. All authors have read and agreed to the published version of the manuscript.

Funding: This study was supported by the National Natural Science Foundation of China (31660732), the Project of Preeminent Youth Fund of Gansu Province (1506RJDA002), and the Innovation Foundation of Gansu Agriculture University (GAU-QDFC-2018-10). Science Research Fund of Animal Husbandry Post-doctor of Gansu Agricultural University, Agricultural Science and Technology Innovational Fund of Gansu Province (GNCX-2014-30), and Basic Scientific Research Service Fee for Colleges and Universities of Gansu Province.

Conflicts of Interest: The authors declare no conflicts of interest. 


\section{References}

1. Kiyokawa, E.; Takai, S.; Tanaka, M.; Iwase, T.; Suzuki, M.; Xiang, Y.; Naito, Y.; Yamada, K.; Sugimura, H.; Kino, I. Overexpression of ERK, an EPH family receptor protein tyrosine kinase, in various human tumors. Cancer Res. 1994, 54, 3645-3650.

2. Iwase, T.; Tanaka, M.; Suzuki, M.; Naito, Y.; Sugimura, H.; Kino, I. Identification of Protein-Tyrosine Kinase Genes Preferentially Expressed in Embryo Stomach and Gastric Cancer. Biochem. Biophys. Res. Commun. 1993, 194, 700-705. [CrossRef]

3. Widmann, C.; Gibson, S.; Jarpe, M.B.; Johnson, G.L. Mitogen-activated protein kinase: Conservation of a three-kinase module from yeast to human. Physiol. Rev. 1999, 79, 143-180. [CrossRef] [PubMed]

4. Johnson, G.L.; Lapadat, R. Mitogen-activated protein kinase pathways mediated by ERK, JNK, and p38 protein kinases. Science 2002, 298, 1911-1912. [CrossRef] [PubMed]

5. Lu, Z.; Xu, S. ERK1/2 MAP kinases in cell survival and apoptosis\&nbsp. IUBMB Life 2008, 58, 621-631.

6. Erhardt, P.; Schremser, E.J.; Cooper, G.M. B-Raf inhibits programmed cell death downstream of cytochrome c release from mitochondria by activating the MEK/Erk pathway. Mol. Cell. Biol. 1999, 19, 5308-5315. [CrossRef] [PubMed]

7. Park, J.S.; Carter, S.; Reardon, D.B.; Schmidt-Ullrich, R.; Dent, P.; Fisher, P.B. Roles for basal and stimulated p21(Cip-1/WAF1/MDA6) expression and mitogen-activated protein kinase signaling in radiation-induced cell cycle checkpoint control in carcinoma cells. Mol. Biol. Cell 1999, 10, 4231-4246. [CrossRef] [PubMed]

8. Kitagawa, D.; Tanemura, S.; Ohata, S.; Shimizu, N.; Seo, J.; Nishitai, G.; Watanabe, T.; Nakagawa, K.; Kishimoto, H.; Wada, T.; et al. Activation of extracellular signal-regulated kinase by ultraviolet is mediated through Src-dependent epidermal growth factor receptor phosphorylation. Its implication in an anti-apoptotic function. J. Biol. Chem. 2002, 277, 366-371. [CrossRef]

9. Lu, Z.; Xu, S.; Joazeiro, C.; Cobb, M.H.; Hunter, T. The PHD domain of MEKK1 acts as an E3 ubiquitin ligase and mediates ubiquitination and degradation of ERK1/2. Mol. Cell 2002, 9, 945-956. [CrossRef]

10. Nagata, Y.; Todokoro, K. Requirement of activation of JNK and p38 for environmental stress-induced erythroid differentiation and apoptosis and of inhibition of ERK for apoptosis. Blood 1999, 94, 853-863. [CrossRef]

11. Tran, S.E.; Holmstrom, T.H.; Ahonen, M.; Kahari, V.M.; Eriksson, J.E. MAPK/ERK overrides the apoptotic signaling from Fas, TNF, and TRAIL receptors. J. Biol. Chem. 2001, 276, 16484-16490. [CrossRef] [PubMed]

12. Kim, S.J.; Ju, J.W.; Oh, C.D.; Yoon, Y.M.; Song, W.K.; Kim, J.H.; Yoo, Y.J.; Bang, O.S.; Kang, S.S.; Chun, J.S. ERK-1/2 and p38 kinase oppositely regulate nitric oxide-induced apoptosis of chondrocytes in association with p53, caspase-3, and differentiation status. J. Biol. Chem. 2002, 277, 1332-1339. [CrossRef] [PubMed]

13. Wang, X.; Martindale, J.L.; Liu, Y.; Holbrook, N.J. The cellular response to oxidative stress: Influences of mitogen-activated protein kinase signalling pathways on cell survival. Biochem. J. 1998, 333 Pt 2, 291-300. [CrossRef]

14. Buckley, S.; Driscoll, B.; Barsky, L.; Weinberg, K.; Anderson, K.; Warburton, D. ERK activation protects against DNA damage and apoptosis in hyperoxic rat AEC2. Am. J. Physiol. 1999, 277, L159-L166. [CrossRef] [PubMed]

15. Karagiota, A.; Kourti, M.; Simos, G.; Mylonis, I. HIF-1 $\alpha$-derived cell-penetrating peptides inhibit ERK-dependent activation of HIF-1 and trigger apoptosis of cancer cells under hypoxia. Cell. Mol. Life Sci. 2018, 76, 809-825. [CrossRef]

16. Mottet, D.; Michel, G.; Renard, P.; Ninane, N.; Raes, M.; Michiels, C. Role of ERK and calcium in the hypoxia-induced activation of HIF-1. J. Cell Physiol. 2003, 194, 30-44. [CrossRef]

17. Minet, E.; Arnould, T.; Michel, G.; Roland, I.; Mottet, D.; Raes, M.; Remacle, J.; Michiels, C. ERK activation upon hypoxia: Involvement in HIF-1 activation. FEBS Lett. 2000, 468, 53-58. [CrossRef]

18. Almog, T.; Naor, Z. Mitogen activated protein kinases (MAPKs) as regulators of spermatogenesis and spermatozoa functions. Mol. Cell. Endocrinol. 2008, 282, 39-44. [CrossRef]

19. Tong, J.S.; Zhang, Q.H.; Huang, X.; Fu, X.Q.; Qi, S.T.; Wang, Y.P.; Hou, Y.; Sheng, J.; Sun, Q.Y. Icaritin causes sustained ERK1/2 activation and induces apoptosis in human endometrial cancer cells. PLoS ONE 2011, 6, e16781. [CrossRef]

20. Samuels, I.S.; Karlo, J.C.; Faruzzi, A.N.; Pickering, K.; Herrup, K.; Sweatt, J.D.; Saitta, S.C.; Landreth, G.E. Deletion of ERK2 Mitogen-Activated Protein Kinase Identifies Its Key Roles in Cortical Neurogenesis and Cognitive Function. J. Neurosci. 2008, 28, 6983-6995. [CrossRef] 
21. Wang, Y.; Kristensen, G.B.; Helland, A.; Nesland, J.M.; Borresen-Dale, A.L.; Holm, R. Protein expression and prognostic value of genes in the erb-b signaling pathway in advanced ovarian carcinomas. Am. J. Clin. Pathol. 2005, 124, 392-401. [CrossRef]

22. Wong, C.H.; Cheng, C.Y. Mitogen-activated protein kinases, adherens junction dynamics, and spermatogenesis: A review of recent data. Dev. Biol. 2005, 286, 1-15. [CrossRef] [PubMed]

23. Li, Q.; Bao, F.; Zhi, D.; Liu, M.; Yan, Q.; Zheng, X.; Ren, L.; Cong, S.; Li, Y.; Cao, G. Lipopolysaccharide induces SBD-1 expression via the P38 MAPK signaling pathway in ovine oviduct epithelial cells. Lipids Health Dis. 2016, 15, 127-136. [CrossRef] [PubMed]

24. Pan, H.; Cui, H.; Liu, S.; Yu, Q.; Wu, H.; Liang, L.; Guan, Y.; Xin, G.; Long, Z.; Fan, H.Y. Lgr4 Gene Regulates Corpus Luteum Maturation Through Modulation of the WNT-Mediated EGFR-ERK Signaling Pathway. Endocrinology 2014, 155, 3624-3637. [CrossRef] [PubMed]

25. Schuermann, Y.; Rovani, M.T.; Gasperin, B.; Ferreira, R.; Ferst, J.; Madogwe, E.; Gonçalves, P.B.; Bordignon, V.; Duggavathi, R. ERK1/2-dependent gene expression in the bovine ovulating follicle. Sci. Rep. 2018, 8, 16170. [CrossRef] [PubMed]

26. Ryan, K.E.; Casey, S.M.; Canty, M.J.; Crowe, M.A.; Martin, F.; Evans, A.C.O. Akt and Erk signal transduction pathways are early markers of differentiation in dominant and subordinate ovarian follicles in cattle. Reproduction 2007, 133, 617-626. [CrossRef]

27. Choi, J.; Jo, M.; Lee, E.; Choi, D. ERK1/2 is involved in luteal cell autophagy regulation during corpus luteum regression via an mTOR-independent pathway. Mol. Hum. Reprod. 2014, 20, 972-980. [CrossRef]

28. Lee, J.H.; Banu, S.K.; McCracken, J.A.; Arosh, J.A. Early pregnancy modulates survival and apoptosis pathways in the corpus luteum in sheep. Reproduction 2016, 151, 187-202. [CrossRef]

29. Wang, J.; Huang, X.; Zhang, K.; Mao, X.; Ding, X.; Zeng, Q.; Bai, S.; Xuan, Y.; Peng, H. Vanadate oxidative and apoptotic effects are mediated by the MAPK-Nrf2 pathway in layer oviduct magnum epithelial cells. Metallomics 2017, 9, 1562-1575. [CrossRef]

30. Crepieux, P.; Marion, S.; Martinat, N.; Fafeur, V.; Vern, Y.L.; Kerboeuf, D.; Guillou, F.; Reiter, E. The ERK-dependent signalling is stage-specifically modulated by FSH, during primary Sertoli cell maturation. Oncogene 2001, 20, 4696-4709. [CrossRef]

31. Lu, Q.; Sun, Q.Y.; Breitbart, H.; Chen, D.Y. Expression and phosphorylation of mitogen-activated protein kinases during spermatogenesis and epididymal sperm maturation in mice. Arch. Androl. 1999, 43, 55-66. [CrossRef] [PubMed]

32. Sette, C.; Barchi, M.; Bianchini, A.; Conti, M.; Rossi, P.; Geremia, R. Activation of the mitogen-activated protein kinase ERK1 during meiotic progression of mouse pachytene spermatocytes. J. Biol. Chem. 1999, 274, 33571-33579. [CrossRef] [PubMed]

33. Ji, Q.M. Advances in research of yak resources in China. J. Nat. Resour. 2001, 16, 564-569.

34. Qiu, Q.; Zhang, G.; Ma, T.; Qian, W.; Wang, J.; Ye, Z.; Cao, C.; Hu, Q.; Kim, J.; Larkin, D.M.; et al. The yak genome and adaptation to life at high altitude. Nat. Genet. 2012, 44, 946-949. [CrossRef]

35. Mann, G.E. Reproduction in the yak. Br. Vet. J. 1993, 149, 513-514. [CrossRef]

36. Zi, X.D. Reproduction in female yaks (Bos grunniens) and opportunities for improvement. Theriogenology 2003, 59, 1303-1312. [CrossRef]

37. Lan, D.; Xiong, X.; Huang, C.; Mipam, T.D.; Li, J. Toward Understanding the Genetic Basis of Yak Ovary Reproduction: A Characterization and Comparative Analyses of Estrus Ovary Transcriptiome in Yak and Cattle. PLOS ONE 2016, 11, e0152675. [CrossRef]

38. Yu, S.J.; Huang, Y.M.; Chen, B.X. Reproductive patterns of the yak. III. Levels of progesterone and oestradiol-17 $\beta$ during pregnancy and the periparturient period. Br. Vet. J. 1993, 149, 595-602. [CrossRef]

39. Yu, S.J.; Huang, Y.M.; Chen, B.X. Reproductive patterns of the yak. II. Progesterone and oestradiol-17 $\beta$ levels in plasma and milk just before the breeding season; also during normal and short oestrous cycles. Br. Vet. J. 1993, 149, 585-593. [CrossRef]

40. JiangFeng, F.; Jiu, Y.; Wen, Z.; Ben, L. The expression of Fas/FasL and apoptosis in yak placentomes. Anim. Reprod. Sci. 2011, 128, 107-116. [CrossRef]

41. Fan, J.; Yu, S.; Cui, Y.; Xu, G.; Wang, L.; Pan, Y.; He, H. Bcl-2/Bax protein and mRNA expression in yak (Bos grunniens) placentomes. Theriogenology 2017, 104, 23-29. [CrossRef] [PubMed]

42. Radi, Z.; Khan, N. Comparative Expression and Distribution of c-fos, Estrogen Receptor $\alpha$ (ER $\alpha)$, and p38 $\alpha$ in the Uterus of Rats, Monkeys, and Humans. Toxicol. Pathol. 2006, 34, 327-335. [CrossRef] [PubMed] 
43. Radi, Z.; Marusak, R.; Morris, D. Species Comparison of the Role of p38 MAP Kinase in the Female Reproductive System. J. Toxicol. Pathol. 2009, 22, 109-124. [CrossRef] [PubMed]

44. Richards, J.S.; Pangas, S.A. The ovary: Basic biology and clinical implications. J. Clin. Investig. 2010, 120, 963-972. [CrossRef] [PubMed]

45. Su, Y.Q.; Wigglesworth, K.; Pendola, F.L.; O’Brien, M.J.; Eppig, J.J. Mitogen-activated protein kinase activity in cumulus cells is essential for gonadotropin-induced oocyte meiotic resumption and cumulus expansion in the mouse. Endocrinology 2002, 143, 2221-2232. [CrossRef] [PubMed]

46. Ryan, K.E.; Glister, C.; Lonergan, P.; Martin, F.; Knight, P.G.; Evans, A.C. Functional significance of the signal transduction pathways Akt and Erk in ovarian follicles: In vitro and in vivo studies in cattle and sheep. J. Ovarian Res. 2008, 1, 2. [CrossRef]

47. Henriquez, S.; Kohen, P.; Munoz, A.; Godoy, A.; Orge, F.; Strauss, J.F., 3rd; Devoto, L. In-vitro study of gonadotrophin signaling pathways in human granulosa cells in relation to progesterone receptor expression. Reprod. Biomed. Online 2017, 35, 363-371. [CrossRef]

48. Zhang, X.Y.; Chang, H.M.; Taylor, E.L.; Liu, R.Z.; Leung, P.C.K. BMP6 Downregulates GDNF Expression Through SMAD1/5 and ERK1/2 Signaling Pathways in Human Granulosa-Lutein Cells. Endocrinology 2018, 159, 2926-2938. [CrossRef]

49. Yamashita, Y.; Hishinuma, M.; Shimada, M. Activation of PKA, p38 MAPK and ERK1/2 by gonadotropins in cumulus cells is critical for induction of EGF-like factor and TACE/ADAM17 gene expression during in vitro maturation of porcine COCs. J. Ovarian Res. 2009, 2, 20. [CrossRef]

50. Wayne, C.M.; Fan, H.Y.; Cheng, X.; Richards, J.S. Follicle-stimulating hormone induces multiple signaling cascades: Evidence that activation of Rous sarcoma oncogene, RAS, and the epidermal growth factor receptor are critical for granulosa cell differentiation. Mol. Endocrinol. 2007, 21, 1940-1957. [CrossRef]

51. Siddappa, D.; Beaulieu, E.; Gevry, N.; Roux, P.P.; Bordignon, V.; Duggavathi, R. Effect of the transient pharmacological inhibition of Mapk3/1 pathway on ovulation in mice. PLoS ONE 2015, 10, e0119387. [CrossRef] [PubMed]

52. Su, Y.Q.; Nyegaard, M.; Overgaard, M.T.; Qiao, J.; Giudice, L.C. Participation of mitogen-activated protein kinase in luteinizing hormone-induced differential regulation of steroidogenesis and steroidogenic gene expression in mural and cumulus granulosa cells of mouse preovulatory follicles. Biol. Reprod. 2006, 75, 859-867. [CrossRef] [PubMed]

53. Fan, H.Y.; Liu, Z.; Shimada, M.; Sterneck, E.; Johnson, P.F.; Hedrick, S.M.; Richards, J.S. MAPK3/1 (ERK1/2) in ovarian granulosa cells are essential for female fertility. Science 2009, 324, 938-941. [CrossRef] [PubMed]

54. Cooke, I.D. The corpus luteum. Hum. Reprod. 1988, 3, 153-156. [CrossRef]

55. Maekawa, R.; Lee, L.; Okada, M.; Asada, H.; Shinagawa, M.; Tamura, I.; Sato, S.; Tamura, H.; Sugino, N. Changes in gene expression of histone modification enzymes in rat granulosa cells undergoing luteinization during ovulation. J. Ovarian Res. 2016, 9, 15. [CrossRef] [PubMed]

56. Qi, L.; Jiang, J.; Jin, P.; Kuang, M.; Wei, Q.; Shi, F.; Mao, D. Expression patterns of claudin-5 and its related signals during luteal regression in pseudopregnant rats: The enhanced effect of additional PGF treatment. Acta Histochem. 2018, 120, 221-227. [CrossRef]

57. Chen, D.B.; Davis, J.S. Epidermal growth factor induces c-fos and c-jun mRNA via Raf-1/MEK1/ERK-dependent and -independent pathways in bovine luteal cells. Mol. Cell. Endocrinol. 2003, 200, 141-154. [CrossRef]

58. Rueda, B.R.; Hendry, I.R.; Ndjountche, L.; Suter, J.; Davis, J.S. Stress-induced mitogen-activated protein kinase signaling in the corpus luteum. Mol. Cell. Endocrinol. 2000, 164, 59-67. [CrossRef]

59. Wang, H.; Guo, Y.; Wang, D.; Kingsley, P.J.; Marnett, L.J.; Das, S.K.; DuBois, R.N.; Dey, S.K. Aberrant cannabinoid signaling impairs oviductal transport of embryos. Nat. Med. 2004, 10, 1074-1080. [CrossRef]

60. Lopez-Cardona, A.P.; Perez-Cerezales, S.; Fernandez-Gonzalez, R.; Laguna-Barraza, R.; Pericuesta, E.; Agirregoitia, N.; Gutierrez-Adan, A.; Agirregoitia, E. CB1 cannabinoid receptor drives oocyte maturation and embryo development via PI3K/Akt and MAPK pathways. FASEB J. 2017, 31, 3372-3382. [CrossRef]

61. Leese, H.J.; Hugentobler, S.A.; Gray, S.M.; Morris, D.G.; Sturmey, R.G.; Whitear, S.-L.; Sreenan, J.M. Female reproductive tract fluids: Composition, mechanism of formation and potential role in the developmental origins of health and disease. Reprod. Fertil. Dev. 2007, 20, 1-8. [CrossRef] [PubMed]

62. Buhi, W.C.; Alvarez, I.M.; Kouba, A.J. Secreted proteins of the oviduct. Cells Tissues Organs 2000, 166, 165-179. [CrossRef] [PubMed] 
63. Bauersachs, S.; Rehfeld, S.; Ulbrich, S.E.; Mallok, S.; Prelle, K.; Wenigerkind, H.; Einspanier, R.; Blum, H.; Wolf, E. Monitoring gene expression changes in bovine oviduct epithelial cells during the oestrous cycle. J. Mol. Endocrinol. 2004, 32, 449-466. [CrossRef] [PubMed]

64. Cerny, K.L.; Garrett, E.; Walton, A.J.; Anderson, L.H.; Bridges, P.J. A transcriptomal analysis of bovine oviductal epithelial cells collected during the follicular phase versus the luteal phase of the estrous cycle. Reprod. Biol. Endocrinol. 2015, 13, 84. [CrossRef] [PubMed]

65. Soleilhavoup, C.; Riou, C.; Tsikis, G.; Labas, V.; Harichaux, G.; Kohnke, P.; Reynaud, K.; de Graaf, S.P.; Gerard, N.; Druart, X. Proteomes of the Female Genital Tract During the Oestrous Cycle. Mol. Cell. Proteom. 2016, 15, 93-108. [CrossRef] [PubMed]

66. Lamy, J.; Labas, V.; Harichaux, G.; Tsikis, G.; Mermillod, P.; Saint-Dizier, M. Regulation of the bovine oviductal fluid proteome. Reproduction 2016, 152, 629-644. [CrossRef]

67. Acuña, O.; Avilés, M.; López-Úbeda, R.; Guillen-Martinez, A.; Soriano-Úbeda, C.; Torrecillas, A.; Coy, P.; Izquierdo Rico, M.J. Differential gene expression in porcine oviduct during the oestrous cycle. Reprod. Fertil. Dev. 2017, 29, 2387-2399. [CrossRef]

68. Seytanoglu, A.; Georgiou, A.S.; Sostaric, E.; Watson, P.F.; Holt, W.V.; Fazeli, A. Oviductal cell proteome alterations during the reproductive cycle in pigs. J. Proteome Res. 2008, 7, 2825-2833. [CrossRef]

69. Tone, A.A.; Begley, H.; Sharma, M.; Murphy, J.; Rosen, B.; Brown, T.J.; Shaw, P.A. Gene expression profiles of luteal phase fallopian tube epithelium from BRCA mutation carriers resemble high-grade serous carcinoma. Clin. Cancer Res. 2008, 14, 4067-4078. [CrossRef]

70. George, S.H.; Greenaway, J.; Milea, A.; Clary, V.; Shaw, S.; Sharma, M.; Virtanen, C.; Shaw, P.A. Identification of abrogated pathways in fallopian tube epithelium from BRCA1 mutation carriers. J. Pathol. 2011, 225, 106-117. [CrossRef]

71. Haschek, W.M.; Rousseaux, C.G.; Wallig, M.A. Handbook of Toxicologic Pathology; Academic Press: San Diego, CA, USA, 2002; pp. 47-894.

72. Marusak, R.A.; Radi, Z.A.; Obert, L. Expression of Ki-67 in the uterus during various stages of the estrous cycle in rats. Exp. Toxicol. Pathol. 2007, 59, 151-155. [CrossRef] [PubMed]

73. Chen, B.; Pan, H.; Zhu, L.; Deng, Y.; Pollard, J.W. Progesterone inhibits the estrogen-induced phosphoinositide 3-kinase->AKT->GSK-3beta->cyclin D1->pRB pathway to block uterine epithelial cell proliferation. Mol. Endocrinol. 2005, 19, 1978-1990. [CrossRef] [PubMed]

74. Lessey, B. Two pathways of progesterone action in the human endometrium: Implications for implantation and contraception. Steroids 2003, 68, 809-815. [CrossRef] [PubMed]

75. Kokatam, S.; Blesson, C.; Fatima, I.; Kitchlu, S.; Jain, S.; Mehrotra, P.; Dwivedi, A. Expression of $\alpha \mathrm{V} \beta 3$ integrin in rat endometrial epithelial cells and its functional role during implantation. Gen. Comp. Endocrinol. 2008, 160, 124-133.

76. Okulicz, W.C.; Ace, C.I.; Longcope, C.; Tast, J. Analysis of differential gene regulation in adequate versus inadequate secretory-phase endometrial complementary deoxyribonucleic acid populations from the rhesus monkey. Endocrinology 1996, 137, 4844-4850. [CrossRef]

77. Thienel, T.; Chwalisz, K.; Winterhager, E. Expression of MAPkinases (Erk1/2) during decidualization in the rat: Regulation by progesterone and nitric oxide. Mol. Hum. Reprod. 2002, 8, 465-474. [CrossRef]

78. Casals, G.; Ordi, J.; Creus, M.; Fabregues, F.; Casamitjana, R.; Quinto, L.; Campo, E.; Balasch, J. Osteopontin and alphavbeta3 integrin expression in the endometrium of infertile and fertile women. Reprod. Biomed. Online 2008, 16, 808-816. [CrossRef]

79. Sayem, A.S.M.; Giribabu, N.; Muniandy, S.; Salleh, N. Effects of thyroxine on expression of proteins related to thyroid hormone functions (TR-alpha, TR-beta, RXR and ERK1/2) in uterus during peri-implantation period. Biomed. Pharm. 2017, 96, 1016-1021. [CrossRef]

80. Welsh, T.; Johnson, M.; Yi, L.; Tan, H.; Rahman, R.; Merlino, A.; Zakar, T.; Mesiano, S. Estrogen receptor (ER) expression and function in the pregnant human myometrium: Estradiol via ERalpha activates ERK1/2 signaling in term myometrium. J. Endocrinol. 2012, 212, 227-238. [CrossRef] [PubMed]

(C) 2020 by the authors. Licensee MDPI, Basel, Switzerland. This article is an open access article distributed under the terms and conditions of the Creative Commons Attribution (CC BY) license (http://creativecommons.org/licenses/by/4.0/). 